\title{
Presencia de prácticos y profesionistas en las haciendas azucareras morelenses de los hermanos García Icazbalceta, 1877-1894
}

Practical people and professionals in the Morelos sugar plantations of the García Icazbalceta brothers, 1877-1894

Emma Rivas Mata

Edgar O. Gutiérrez

Resumen

Palabras clave

Abstract

Keywords
Investigadora de la Dirección de Estudios Históricos del Instituto Nacional de Antropología e Historia. Maestra en Historia de México por la Universidad Nacional Autónoma de México. Entre sus publicaciones se cuentan Bibliografías novohispanas o historia de varones eruditos (México, INAH, 2000) y Entretenimientos literarios. Epistolario entre Joaquín García Icazbalceta y Manuel Remón Zarco del Valle, 1868-1886 (México, INAH, 2003), entre otros. Su correo electrónico es: erivas.deh@ inah.gob.mx.

Investigador de la Dirección de Estudios Históricos del Instituto Nacional de Antropología e Historia. Maestro en Sociología por la Universidad Nacional Autónoma de México. Es coautor de Una vida entre libros II. Testimonios de Ernesto López Yescas (Hermosillo, Gobierno del Estado de Sonora, Secretaría de Educación y Cultura, 1997), y Libros y exilio. Epistolario de José Fernando Ramírez con Joaquín García Icazbalceta y otros corresponsales, 1838-1870 (México, INAH, 2010) Su correo electrónico es: egutierrez.deh@inah.gob.mx.

El artículo muestra cómo las labores realizadas por algunos ingenieros, administradores y otro tipo de personal capacitado incidieron en la buena marcha de las haciendas azucareras de los hermanos García Icazbalceta. La presencia de trabajadores calificados también constituye un testimonio de la modernización llevada a cabo en estas fincas en buena parte del último cuarto del siglo XIX.

Joaquín García Icazbalceta, “escritorio”, haciendas, modernización, azúcar.

The article shows how the work done by some engineers, managers and other skilled personnel, emphasized the smooth running of the sugar estates Icazbalceta Brothers. The presence of skilled workers is also a testimony of modernization carried out on these farms, in much of the last quarter of the nineteenth century.

Joaquín García Icazbalceta, “desk”, ranches, modernization, sugar.

Recibido/Received 5 de abril, 2013

Aprobado/Approved 24 de febrero, 2014

Este artículo fue dictaminado por especialistas de forma anónima.

This article has been peer reviewed. 


\section{Presencia de prácticos y profesionistas}

en las haciendas azucareras morelenses

de los hermanos García Icazbalceta, 1877-1894

Emma Rivas Mata

Edgar O. Gutiérrez

Introducción

La presencia de algunos prácticos ${ }^{1}$ y profesionistas en las haciendas delos hermanos García Icazbalceta fue una constante e incidió en su modernización y buena marcha. Si bien el trabajo de las haciendas recaía en una gran variedad de operarios, maestros, peones, albañiles, etcétera, supervisados por el administrador y dirigidos por el hacendado mismo, este artículo refiere diversas actividades que desempeñaron en particular algunos prácticos y profesionistas, varios de ellos extranjeros, en las fincas azucareras morelenses propiedad de la compañía García Icazbalceta Hermanos, en el periodo de 1877 a 1894.

Mediante estas actividades puede observarse que una de las principales preocupaciones de los propietarios de dichas haciendas fue mejorar e incrementar año con año la producción de azúcar, mieles, aguardiente y demás productos, pero también algo muy importante: reducir los costos de producción. Tales indicios bien pueden caracterizar a estas haciendas como "modernas", en un sentido amplio del término.

Antes de entrar en el tema relativo a los prácticos y profesionistas que prestaron sus servicios en las haciendas de la compañía García Icazbalceta Hermanos durante el periodo señalado, es importante tener presente el 
contexto general de la época, que varios estudiosos de la industria azucarera mexicana han señalado como el de la "modernización tecnológica". Algunos autores coinciden en señalar que este proceso inició fundamentalmente a partir dela década de 1880 y continuó a lo largo dela siguiente. ${ }^{2}$

Durante estos años de régimen porfirista maduraron las condiciones políticas y económicas para lograr una importante expansión delos campos cañeros, gracias a los cambios en la infraestructura hidráulica, es decir a la ampliación y modernización del sistema deirrigación, punto fundamental para el aumento de la producción de caña. Un ejemplo es la hacienda de Tenango, en donde se construyeron los canales del río del mismo nombre, los cuales llegaron a tener $52 \mathrm{~km}$ de extensión, 11 túneles y dos acueductos; esto permitió que la hacienda pudiera "incrementar [en] 450 hectáreas la zona de riego" y dotar de agua a esta importante finca. ${ }^{3}$

Las obras hidráulicas se vieron acompañadas de la introducción del ferrocarril y el cambio de sistemas tradicionales de tracción animal por los de vapor, fundamental en dicha modernización. Por su parte, Joaquín García Icazbalceta, principal responsable de las haciendas en cuestión, preocupado por aumentar la producción, reducir costos, mejorar la calidad de sus productos y ampliar sus mercados, echó mano de sus amplios conocimientos en cuestiones mercantiles, de la búsqueda de información diaria en los periódicos de la época, ${ }^{4}$ así como de su red de corresponsales, para adquirir maquinaria, realizar obras de construcción, documentarse sobre temas agrícolas y estar al tanto de las novedades tecnológicas relativas al cultivo de la caña y la elaboración del dulce, mieles y aguardiente. ${ }^{5}$

2 Horacio Crespo (dir.), Sergio Reyes Retana, Enrique Vega Villanueva et al., Historia del azúcar en México, 2 v., México, Azúcar/Fondo de Cultura Económica, 1988, v. 1, p. $13,97$.

3 Ibidem, p. 97.

4 Joaquín García Icazbalceta, quien era un buen lector de periódicos, en sus cartas hace constantes referencias a algunos de los diarios que recibía en las haciendas, entre otros: El Monitor Republicano, El Centinela, La Colonia Española, La Libertad, El Siglo Diez y Nueve, La Ilustración Española, La Patria y La Ilustración Católica. Mientras tanto, la siempre compañera de sus viajes a las fincas, su hija María, recibía La Moda Elegante y El Mensajero Católico. 5 Joaquín García Icazbalceta logró formar una red de más de 300 corresponsales establecidos en las principales capitales de Estados Unidos, Europa y América del Sur. Entre ellos se encontraban historiadores, literatos y otros estudiosos con quienes discutía cuestiones relativas a sus investigaciones históricas y bibliográficas; pero también tenía comunicación con libreros, bibliotecarios y comisionistas que le surtían libros, conseguían copias de documentos, material tipográfico y bibliografía actualizada en cuestiones agrícolas y maquinaria para 
Todas las obras realizadas, la aplicación de mejores técnicas, la renovación de maquinaria y el empleo de personal capacitado y experimentado en sus haciendas, además de una eficiente administración y supervisión constante, le permitió a la compañía García Icazbalceta Hermanos distinguirse entre los productores de azúcar del estado de Morelos. En particular a Joaquín García Icazbalceta, ya que - sin tener estudios propiamente dichos de agricultura, ingeniería, arquitectura u otras disciplinas pero sí con mucha disciplina autodidacta, capacidad organizativa, observación y un gran sentido de responsabilidad- consiguió equipar sus haciendas con una infraestructura tecnológica de punta, que posteriormente capitalizaría con creces su hijo Luis García Pimentel.

Así entonces, una aproximación a los distintos casos de prácticos y profesionistas empleados, además de dar cuenta delas estrategias de estos hacendados para lograr sus metas, también nos acerca a la vida cotidiana y a las labores agrícolas de las fincas azucareras de la compañía citada; lo mismo que a las relaciones familiares de sus dueños, al trato de éstos con sus empleados, a la convivencia de las haciendas con los pueblos de la región, al problema del agua entre ambos y algunos otros aspectos en donde se muestra que la presencia de estos prácticos y profesionistas - entre los que encontramos carpinteros, cobreros, herreros, ingenieros, abogados, médicos, preceptores, administradores y más- fue fundamental para la marcha de las haciendas.

Para este artículo utilizamos como fuente principal un grupo de 333 cartas personales que hemos denominado "Cartas de las haciendas", escritas por Joaquín García Icazbalceta a su hijo Luis García Pimentel, entre 1877 y 1894, años de trabajo muy intenso y previos a su retiro al frente de las fincas azucareras. ${ }^{6}$ Estas misivas tenían como objetivo mantener

sus haciendas. Su experiencia en el comercio y las operaciones de exportación de azúcar e importación de ultramarinos, así como los contactos comerciales de la familia, le facilitaron el establecimiento de estos vínculos y la realización de compras. Para mayor información sobre sus corresponsales, véase el artículo de Emma Rivas Mata, "Estrategias bibliográficas de Joaquín García Icazbalceta”, Istor. Revista de historia internacional, México, Centro de Investigación y Docencia Económicas, año VIII, n. 31, invierno de 2007, p. 118-148.

6 Emma Rivas Mata y Edgar O. Gutiérrez (comp.), Cartas de las haciendas. Joaquín García Icazbalceta escribe a su hijo Luis, 1877-1894, México, Instituto Nacional de Antropología e Historia, 2013, 659 p. (Colección Historia, Serie Sumaria). 
informado a su hijo sobre el complejo manejo de sus haciendas llamadas Santa Ana Tenango, Santa Clara de Montefalco y San Ignacio Urbieta con sus anexos, las tres ubicadas en lajurisdicción de J onacatepec, al oriente del actual estado de Morelos, ${ }^{7}$ y prepararlo para asumir su dirección llegado el momento. Así, estas cartas hoy bien pueden ser consideradas un manual de enseñanza y aprendizaje para la administración de dichas haciendasy, particularmente, permiten tener una aproximación ala actuación del bibliógrafo e historiador Joaquín García Icazbalceta en su papel de hacendado, aspecto hasta ahora poco abordado.

Es importante señalar que si bien la riqueza de esta fuente es indudable para el estudio de muy diversos aspectos de las haciendas, de la industria del azúcar, del comercio y más, en este artículo centramos la atención en aquella información que documenta el trabajo de personal calificado y experimentado en las haciendas, como una estrategia más de los García Icazbalceta en el temprano proceso de modernización tecnológica de sus fincas azucareras.

\section{La compañía García Icazbalceta Hermanos}

Brevemente diremos que esta compañía tiene su origen en la hacienda Santa Clara Montefalco, la cual inicialmente heredó y formó parte de la dote de Ana Ramona de Icazbalceta y Musitu al casarse, en 1809, con el comerciante español Eusebio García Monasterio, quien desde entonces tomó la finca a su cargo. El matrimonio García Icazbalceta tuvo en total once hijos pero sólo sobrevivieron ocho de ellos. ${ }^{8}$ Vivían en la calle de la Merced número 3, en el centro de la ciudad de México, y ahí mismo

7 La extensión de las haciendas de los hermanos García Icazbalceta superaba las 68000 hectáreas, prácticamente todo el oriente del actual estado de Morelos. La hacienda Santa Ana Tenango tenía alrededor de 38699 ha, era la más productiva. Le seguía en tamaño Santa Clara Montefalco, con 29482 ha; la más pequeña era San Ignacio Urbieta, que se consideraba una extensión de la de Santa Ana Tenango. Brígida von Mentz, Beatriz Scharrer et al., Haciendas de Morelos, México, Instituto de Cultura de Morelos/Consejo Nacional para la Cultura y las Artes, 1997, 412 p., p. 151-152.

8 Eusebio García Monasterio (1771-1852) y Ana Ramona de Icazbalceta y Musitu (1792-1839) tuvieron once hijos, de los cuales sobrevivieron ocho: José Mariano (1810-1869), María Dolores (1811-1873), Ana María Fernanda (1814-1888), Tomás José (1816-1868), María Ignacia (1818-1876), Lorenzo Librado (1819-1890), María de Jesús (1820-1897) y Joaquín (1821-1894). 
estableció Eusebio García su "escritorio"9 o despacho comercial desdedonde comercializaba los productos de la hacienda y otras mercancías.

Años más tarde, en 1850, Eusebio García adquirió las dos haciendas que habían pertenecido a sus cuñados Nicolás Fernando y María Josefa de Icazbalceta y Musitu, Santa Ana Tenango y San Ignacio Urbieta, respectivamente. ${ }^{10}$ De esta forma Eusebio García, junto con sus cuatro hijos varones, centró sus actividades en atender las tres haciendas azucareras, además de hacerse cargo de otra hacienda llamada El Mayorazgo, ubicada en el Estado de México, también de su propiedad.

A la muerte de Eusebio García Monasterio, en junio de 1852, cinco de sus hijos - José Mariano, Dolores, Tomás, Lorenzo y Joaquín- decidieron formar la compañía "García Icazbalceta Hermanos” con el propósito de mantener unidas sus propiedades rústicas y así dar viabilidad al "escritorio familiar", desde el cual las administraban y vendían sus productos en la ciudad de México y otras plazas. Las tres hermanas, ya casadas -Ana María, María Ignacia y María de Jesús-, recibieron su parte de las haciendas y demás propiedades que les correspondían de la herencia materna y paterna en "dinero efectivo a los términos y plazos convenidos". ${ }^{11}$

Sólo cinco de ellos, los cuatro varones y la hermana mayor, formarían posteriormente la compañía García Icazbalceta Hermanos.

9 Este escritorio, término con el que siempre se referían los García Icazbalceta al despacho comercial que estableció su padre en 1809, estuvo en la calle de la Merced número 3 (actual calle de Venustiano Carranza) hasta fines de 1873. Después, Lorenzo y Joaquín lo tuvieron que cambiar a la calle de Tiburcio número 2 (actual calle de República de Uruguay), en donde permaneció casi dos años más. Finalmente, a partir de agosto de 1875, los dos hermanos decidieron establecerlo en la casa del primero ubicada en la calle de San José El Real (actual calle de Isabel la Católica).

10 Para mayores datos y antecedentes históricos de estas haciendas azucareras y el cambio de sus propietarios, pueden consultarse los siguientes trabajos: María Teresa Huerta, "Los vascos del sector azucarero morelense, 1780-1870", en Los vascos en las regiones de México siglos XVI a XX, coordinación de Amaya Garritz, México, Universidad Nacional Autónoma de México, Instituto de Investigaciones Históricas, 1996, v. 1, p. 237-245; Horacio Crespo (coord.), Morelos, cinco siglos de historia regional, México, Centro de Estudios Históricos del Agrarismo en México/Universidad Autónoma de Morelos, 1984, 464 p.; Brígida von Mentz, Beatriz Scharrer et al., Haciendas de Morelos, y Rivas Mata y Gutiérrez López, Cartas de las haciendas..., entre otros trabajos.

11 Escritura de Compañía, "Archivo General de Notarías de la Ciudad de México, Notario 169, Ramón de la Cueva, 26 de agosto de 1854, f. 194-195v. 
Durante los años que abarcan las "cartas de las haciendas" (1877-1894), periodo al que se ciñe este artículo, sólo quedaban dos propietarios o socios de la compañía, Lorenzo - a quien sus sobrinos llamaban cariñosamente "Pano"- y su hermano menor, Joaquín, apodado por sus hijos "el Tigre". Entonces, el escritorio se encontraba en la casa de Lorenzo, ubicada en la calle de San José El Real, número 13 (actualmente Isabel la Católica).

Según el acuerdo al que llegaron los dos hermanos García Icazbalceta para llevar a cabo el manejo de la compañía, Lorenzo debía fungir como el tesorero del escritorio, mientras que Joaquín era el responsable de llevar los diferentes libros de la contabilidad del negocio, lo cual significaba estar en permanente contacto con los administradores delas haciendas. Además, de acuerdo con el reglamento que tenían establecido, ${ }^{12}$ Joaquín, en quien recaía la mayor responsabilidad de la compañía, estaba obligado a realizar cuando menos una visita anual de dos meses a tierra caliente para supervisar los diferentes trabajos agrícolas y de producción de azúcar y sus derivados. De hecho, la realización de las mencionadas visitas o estancias de Joaquín en las haciendas son el motivo para escribir las cartas a su hijo, quien se quedaba en la ciudad de México auxiliando a su tío en los asuntos relativos al escritorio y así empezar a imponerse de las actividades y obras realizadas en las fincas que un día serían de su propiedad. ${ }^{13}$

12 Por esas misivas hoy sabemos que existió un reglamento donde se regularon las tareas que cada socio debía realizar. Desafortunadamente no hemos podido encontrar dicho documento, el cual nos permitiría señalar de manera más precisa las funciones de cada socio. La existencia del reglamento no sorprende cuando leemos lo que pensaba Joaquín García Icazbalceta sobre la necesidad de plasmar en el papel la reglamentación de cualquier organización. Desde su punto de vista: “Ningún establecimiento en que se reúna un número considerable de personas puede permanecer ordenado, si no es teniendo todos a la vista la regla invariable a que cada uno deba sujetarse. De aquí la necesidad de los reglamentos, que no son una obra de pura inteligencia, como algunos figuran, sino resultado de la larga experiencia y continua observación". Informe sobre los establecimientos de beneficencia y corrección de esta capital; su estado actual; noticia de sus fondos; reformas que desde luego necesitan y plan general de su arreglo, presentado por José María Andrade, Méjico, 1864. Escrito póstumo de don Joaquín García Icazbalceta, publicado por su hijo Luis García Pimentel, individuo correspondiente de la Real Academia de la Historia, de Madrid; miembro de las sociedades de Geografía y de Americanistas, de París, Méjico, Moderna Librería Religiosa de José L. Vallejo, S. en C., Calle de San José el Real número 3/París, en Casa de A. Donnamette, 30, rue des Saints-Pères/ Madrid, Librería de Gabriel Sánchez, Calle de Carretas, N. 21, 1907, IX + 243 p.

13 En 1890, Joaquín García Icazbalceta quedó como único dueño de las haciendas al morir su hermano Lorenzo. Él a su vez heredó por partes iguales todos sus bienes, haciendas, casas, 


\section{Las "obras" en las haciendas}

Fue precisamente por los años de 1878 y 1879 que la compañía García Icazbalceta Hermanos llevaría a cabo diversas modificaciones en sus haciendas de Santa Ana Tenango y Santa Clara Montefalco, sobre todo por iniciativa de don Joaquín. Con el incremento de las tierras irrigadas aumentó la siembra de cañas y, por lo tanto, de las cargas para la molienda. En esta situación, se vieron en la necesidad de introducir un novedoso sistema de tren de vías móviles, conocido como “Decauville”. Apenas unos cuantos años antes, en 1875, el agricultor francés Paul Decauville puso en práctica un sistema de ferrocarril de vía estrecha, de $60 \mathrm{~cm}$, totalmente desmontable y provisto de unos carros o plataformas generalmente movidos por tracción animal. Esto permitía transportar más cargas con mayor facilidad y rapidez. Este práctico sistema pronto se conoció en todo el mundo. Joaquín García Icazbalceta no tardó en introducirlo en sus haciendas para facilitar la transportación delas cañas del campo a la fábrica y después acarrear el azúcar a la estación del ferrocarril central, y de ahí a los distintos puntos para su venta. Cabe señalar que el señor Decauville les puso el nombre de "Tenango" a estas plataformas por ser el nombre de la primera hacienda que las utilizó en México, de acuerdo con el testimonio de Joaquín García Pimentel y Braniff, bisnieto de don Joaquín. ${ }^{14}$

dinero y biblioteca a sus dos únicos hijos, que tuvo con Filomena Pimentel y Heras (18291862): Luis (1855-1930) y María (1860-1916). Luis, por su parte, entre noviembre de 1894, fecha en la cual falleció su padre, y el transcurso del siguiente año, llegó a un acuerdo con su hermana María, representada por su esposo Juan Martínez del Cerro, para darle su parte de la herencia en efectivo. Luis pagaría esa suma a plazos, además de los muebles, las casas, las acciones, así como el cobro de algunos censos, vales e intereses por pagar. De esta forma, Luis García Pimentel quedó como único dueño de las productivas haciendas azucareras en Morelos y de la valiosa biblioteca que logró reunir su padre a lo largo de muchos años, colección que ha sido considerada entre las más importantes para la historia mexicana. Para mayores datos al respecto, véase el "Estudio introductorio" de Cartas de las haciendas...

14 Joaquín García Icazbalceta, Mes y medio en Chiclana o viaje y residencia durante este tiempo en Chiclana y vuelta a Cádiz, por un aficionado a pasearse en esta villa, escrita en la ciudad de Cádiz, año 1835, edición facsimilar, transcripción e introducción de Joaquín García Pimentel y Braniff, México, edición privada, 1987, XII + 43 p.; Beatriz Scharrer, "Los espacios de las haciendas de azúcar hacia fines del siglo XIX”, en Haciendas de Morelos, México, Gobierno del Estado de Morelos/Consejo para la Cultura y las Artes/Miguel Ángel Porrúa, 1997, p. 146, 162; Juana María Rangel Vargas, “Los ferrocarriles portátiles Decauville. Un instrumento de 
En noviembre de 1878, la compañía García Icazbalceta Hermanos empezó por adquirir 18630 libras de rieles y 1065 de placas y tornillos (aproximadamente más de ocho toneladas de rieles y una de placas y tornillos). Aunque esto parecía excesivo le permitiría prolongar la línea aun dentro de los purgares. ${ }^{15}$ Después adquirió las llantas, los cubos y el castillejo, estos últimos los mandó fabricar en una empresa llamada "Las Delicias”, firma bien acreditada en fundición de fierro y bronce, ubicada en la calle del mismo nombre en los límites de la ciudad de México. Las Delicias ofrecía un menor precio y significativos ahorros, lo cual era una preocupación constante de los hermanos García Icazbalceta.

En febrero del año siguiente don Joaquín mandó "hacer el carro para arreglar por él [mismo] la anchura de la vía" y después llamar al "práctico para colocar el ferrocarril de Tenango". Para resolver este problema pensó en llamar a un relojero que tenía mucha experiencia en el arreglo de máquinas y procesos de fundición, de apellido Jacot, posiblemente de origen suizo. ${ }^{16}$

Por las cartas de don Joaquín, se tiene conocimiento del método que siguió para adquirir maquinaria y conseguir algunos materiales en los comercios de la ciudad de México. Consultó primero los catálogos europeos para, después, hacer algún pedido o solicitar presupuestos y proyectos al extranjero; al final casi siempre se inclinaba por intentar hacer las cosas en México con las adaptaciones necesarias. Por lo general, prefería no comentar sus planes de trabajo fuera de su entorno inmediato - es decir,

incidencia mundial”, en Mirada Ferroviaria, Boletín documental, зa. época, n. 6, p. 48 (disponible en: www.museoferrocarriles.org.mx).

15 Carta de Joaquín García Icazbalceta a Luis García Pimentel, México, 27 de noviembre de 1878, en Cartas de las haciendas..., n. 36. En los purgares o casa de purgar, se separaba el azúcar de otros residuos; después de haber procesado el jugo de caña en la casa de calderas, se rellenaban las formas de barro con la masa cocida caliente. Estas formas cónicas se trasladaban a los purgares en donde se enfriarían y se terminaría de purgar el azúcar, es decir, se cristalizaba y escurría la miel y toda la humedad sobrante. Horacio Crespo, Modernización y conflicto social. La hacienda azucarera en el estado de Morelos, 1880-1913, México, Instituto Nacional de Estudios Históricos de las Revoluciones de México, 2009, 459 p., p. 179-180. 16 Carta de Joaquín García Icazbalceta a Luis García Pimentel, Santa Clara, 7 de febrero de 1879 , en Cartas de las haciendas..., n. 73. Podría tratarse de Alejandro Jacot, quien de acuerdo con el censo de 1882 era comerciante suizo de 48 años y tenía joyería, relojería y almacén de máquinas de coser en la primera calle de Plateros Sur, número 4, primer piso. Agradecemos esta información a nuestra colega Dolores Morales. 
sus hijos Luis y María, su hermano Lorenzo, los administradores de las haciendas y sus ayudantes de confianza en el escritorio-. En contadas ocasiones, compartió experiencias y opiniones con administradores de otras fincas relativas a aparatos o mejoras en la producción azucarera, pero invariablemente no le gustaban las intromisiones.

Otro aspecto dela temprana modernización emprendida por los García Icazbalceta fue el reemplazo de una parte de la maquinaria para la fabricación de azúcar y mieles. Los altibajos del mercado azucarero internacional y nacional dieron la pauta para algunos de esos cambios. Adelantándose a otros grandes hacendados, en el año de 1875 ya contaba con algunas centrífugas de la marca francesa "Cail" que eliminaban el "largo y laborioso proceso de purga”, a cambio de rapidez y eficiencia del proceso.

En diciembre de ese mismo año, su comisionista de confianza -el señor A. Donnamette- le remitió desde París otras centrífugas y unas turbinas, además le surtió 200 k de semilla Ray-Grass (para mejorar el rendimiento de sus pastos), dos cajas de papel y los imprescindibles libros a los que don Joaquín dedicaba sus pocos pero muy productivos ratos de ocio entregado a sus "entretenimientos literarios", como él mismo llamó a sus estudios históricos y bibliográficos por los que fue y ha sido ampliamente reconocido. ${ }^{17}$

Para algunos historiadores, la importación de las centrífugas es considerada como el "jalón decisivo" en el proceso modernizador de la industria azucarera del Porfiriato y marcan el año de 1880 como su inicio. Este jalón se lo atribuyen precisamente a Joaquín García Icazbalceta, en lo cual aciertan los estudiosos de estos temas, sólo que fue cinco o seis años más temprano de lo que han señalado. En la correspondencia con su hijo puede constatarse esta precisión temporal. ${ }^{18}$

Como es entendible, los acelerados ritmos del trabajo en las haciendas, el desgaste continuo de la maquinaria y el empeño por obtener mejores ganancias en el menor tiempo, forzaron necesariamente el paso de la "modernidad". De una molienda a otra había que hacer modificaciones o repo-

17 Carta de Joaquín García Icazbalceta a Donnamette y Hattu de París, México, 30 de diciembre de 1875, en Biblioteca Cervantina, Colección Ignacio Bernal del Instituto Tecnológico de Estudios Superiores de Monterrey (en adelante, BCCIB).

18 Crespo, Modernización y conflicto social..., p. 190. 
ner maquinaria, las obras eran constantes aunque a veces iban "a paso de tortuga reumática” - como en muchas ocasiones lo dijo el propio don Joaquín- sin poder activarlas, porque para todo se necesitaba llevar algo de la ciudad de México a las haciendas o forzosamente importarlo de Europa o Estados Unidos, además de esperar la presencia de la persona experimentada para llevar a cabo las obras.

Esta era una de las mayores quejas de "el Tigre" a principios de 1878, cuando se encontró con que el trapiche de la hacienda de Santa Clara estaba completamente parado por falta de chumaceras de "Poulat" que hacían falta para colocar y nivelar las demás piezas. Mientras se conseguían éstas, el ingeniero Luis Bolland tomaba medidas y hacía cálculos para, una vez teniendo todas las piezas, colocar la maquinaria en su lugar.

Un ingeniero de minas en la hacienda de Santa Clara

Así nos encontramos con las obras que realizó Luis Bolland Kuhmackl en las haciendas. Al parecer trabajaba para la ya mencionada fundición "Las Delicias", era austriaco e ingeniero de minas, y fue uno de los tantos profesionistas que trabajaron en las fincas de la compañía García Icazbalceta Hermanos.

Los datos que localizamos de este personaje refieren su llegada a México como parte del cuerpo militar austriaco en apoyo a Maximiliano de Habsburgo. Durante el imperio, Bolland se desempeñó como capitán de ingenieros y formó parte de un grupo de cartógrafos que coordinó el arquitecto Fernando Rosenzweig. El cadete Bolland era un "famoso dibujador" que podía levantar planos de todo género, nivelaciones, construcciones de fortificaciones, caminos, etcétera. También se le atribuye haber sido comisionado por el emperador para diseñar el camino que después se llamaría "Paseo de la Reforma”, el cual se proyectó inicialmente con dos calzadas de $9 \mathrm{~m}$ deancho y dos camellones laterales también de $9 \mathrm{~m}$, a semejanza de algunas grandes avenidas europeas. ${ }^{19}$

19 Herbert J. Nickel, Kaiser Maximilians kartographen in Mexiko, Frankfurt/Main, Vervuert, 2003, p. 9, y José Mancebo Benfield, Las Lomas de Chapultepec. El rancho de Cescoacoaco y el Molino del Rey, México, Porrúa, 1960, p. XV. 
A la caída del imperio, el cadete Bolland, para entonces subteniente de zapadores del ejército mexicano, solicitó al ministro de Guerra permanecer en el país y continuar como encargado del departamento topográfico militar. En los años siguientes, realizó planos de algunas haciendas de Puebla, Tlaxcala e Hidalgo en colaboración con Rosenzweig, con quien en 1871 aparece como autor del plano dela conocida hacienda de Los Morales, dela ciudad de México, elaborado por encargo del entonces dueño de dicha finca, Eduardo Cuevas Rubio. ${ }^{20}$

El grupo de ingenieros austriacos residentes en México, al que pertenecía Bolland, ofrecía sus servicios en

Composición y nivelación de planos militares de todo género y de cartas geográficas; además composiciones de planos geométricos de haciendas, ranchos, pueblos, ciudades enteras, según [los] sistemas más modernos garantizando su exactitud y con la indicación de superficies [...]; nivelación de aguas, construcciones de acueductos y apertura de pozos artesanos [...]; construcción de puentes, calzadas y caminos [...]; construcción de molinos, sierras y otras máquinas para agua o vapor [...]; toda clase de edificios, ya sean de piedra, ladrillo o madera.

Así que en vista de estas impresionantes cartas de presentación, experiencia y aptitudes del ingeniero Bolland, Joaquín García Icazbalceta le encargó algunos arreglos en las haciendas. ${ }^{21}$

En los primeros días de enero de 1878, el ingeniero Bolland estaba trabajando en unas urgencias de la hacienda de Santa Clara; era necesario arreglar lo más pronto posible el trapiche para comenzar la molienda, pero

20 Archivo General de la Nación, Gobernación, Segundo Imperio, caja 50, exp. 46, Secretaría Privada del Emperador, 15 de enero de 1867; Nickel, op. cit., p. 61; Roberto Hernández Malagón (coord.), 500 planos de la ciudad de México, 1325-1933, México, Departamento del Distrito Federal, Secretaría de Asentamientos Humanos y Obras Públicas, 1982.

21 Nickel, op. cit., p. 58. En 1891, Bolland ingresó al Instituto Geológico de México. Héctor Mendoza Vargas, “Agrimensura y cartografía en México, 1720-1920. Exposición por Herbert J. Nickel...”, Boletín, México, Universidad Nacional Autónoma de México, Instituto de Geografía, 61, 2006, p. 148-150 (disponible en: http:illoedalyc.uaemex.mx). Joaquín García Icazbalceta compró mucha maquinaria, herramientas y materiales necesarios de imprenta en el extranjero, por lo mismo contrató varios especialistas extranjeros para su instalación. Tal vez por esta misma razón y en vista de su experiencia empleó a Luis Bolland. 
las cosas no iban del todo bien. La llegada de las chumaceras se retrasaba cada día más; mientras tanto Bolland tomaba medidas y nivelaciones pero continuamente se equivocaba, hacía perder tiempo a los carpinteros mandándoles hacer cosas que después modificaba. Los días pasaban, no se terminaban las composturas y crecía la impaciencia del señor Joaquín García Icazbalceta.

Finalmente llegaron las chumaceras, los maquinistas al mando de Bolland trabajaron cuatro días seguidos y no podían ajustarlas; a la postre, a fuerza de golpes y de limarlas por todas partes quedaron tan rebajadas que de nada había servido mandarlas tornear y esperar que las perfeccionaran en México. Impaciente, don Joaquín observaba las maniobras sin ver resultados; fue necesaria su intervención y la del administrador de la hacienda Santa Clara para agilizar todo, causando el enojo de Bolland.

Don Joaquín relató por carta este molesto incidente a su hijo Luis. Transcribimos aquí gran parte de esa importante y extensa misiva que muestra los conocimientos, dotes organizativas, carácter y oportuna intervención del hacendado para resolver los problemas, así como la participación de diversos y especializados operarios en las obras, como un valioso ejemplo de la complejidad del trabajo en el trapiche:

Me paso las horas en el trapiche criando mala sangre. Esta mañana, aburrido de que Bolland no hacía más que estar viendo, le dije que era preciso que mientras los maquinistas ajustaban, él dirigiera la montada del engrane para ir haciendo algo y quitar las piezas que estaban estorbando mucho allá arriba. Puso algunas dificultades pero insistí, agregando que después de comer había de empezar (eran las 11), y que no le había yo de dar los albañiles y carpinteros que acostumbra emplear como peones, porque los necesitaba yo en otra parte y ganaban mucho, sino una cuadrilla de trapicheros, que están más acostumbrados a mover piezas que los simples peones. Repeló algo, pero tuvo que aceptar. En el acto mandé llamar [a] ocho trapicheros, que andaban en las labores del campo, y para la una estaba lista la cuadrilla. Después de comer me fui al trapiche, donde ya empezaban a trabajar; se trataba de colocar en su lugar el eje de la catarina. Estuve allí más de una hora con don Gregorio, sin decir palabra, viendo que aquello no llevaba camino, ni Bolland ataba ni desataba, porque la flecha ni se movía. 
Empecéa atufarme, y no pudiendo aguantar más, mandé traer el gato, y subiendo a la plataforma con don Gregorio, nos pusimos a mangonear. Sucedió lo que me esperaba, que apenas nos vio Bolland hizo un mal gesto y a poco rato se fue a la puerta del trapiche. En menos de tres cuartos de hora, gracias a la dirección de don Gregorio, que trabajaba personalmente como un peón, estaba la flecha sobre las vigas y rodillos que habían de llevarla a su lugar. Entonces bajé y dije a Bolland que ya estaba arriba la flecha, que podía disponer su colocación. Me contestó de mal modo que la pusiéramos en las chumaceras; le repliqué que eso le tocaba a él, y entonces reventó diciéndome en voz alta, que él no se metía en nada ya que don Gregorio mandaba, y que era preciso ser "muy sinvergüenza" (lo repitió varias veces) para meterse en sus cosas después de lo que había pasado. Al principio le contesté con mucha moderación, que no debía llevar a mal que se le ayudara; pero como siguiera repitiendo lo de "sinvergüenza", echando un gran pollo, pues don Gregorio estaba aparte a seis pasos, hube de molestarme bien, y le dije que don Gregorio no era sinvergüenza, porque si había tomado parte en la operación era porque yo se lo había mandado, viendo que él nada hacía, y que aquel no era lugar de hablar de ese modo, que me siguiera. Lo saqué a la plaza, y allí lo devoré bien, dándole todas mis quejas, con lo cual se amansó. Por último le dije que si él era capaz de hacerlo pronto y bien, que le daba de plazo hasta el martes para que me entregara montado el engrane unido con la rueda, de modo que anduviera echándole agua a ésta; que de aquí a entonces, ni don Gregorio ni yo nos pararíamos siquiera en el trapiche para que quedara en plena libertad; pero que ésta era una prueba definitiva, porque si no cumplía para el martes, tendría yo que tomar providencias. Quedó de acuerdo, y sólo me suplicó mucho que no dejara yo de ir al trapiche, porque lo sentiría mucho, y que bastaba con que no fuera don Gregorio. No le ofrecí que iría; pero haré lo que me convenga. Si cumple, habremos ganado mucho; si no, la misma noche del martes le notifico que se retire con su señora, y me deje solo. A don Gregorio le previne que no se presentara en el trapiche, y le avisé lo convenido. Esperaremos. Félix Lera ha trabajado con tal actividad en la fundición de las chumaceras de abajo, que habiéndole dado el molde el lunes ya tarde, mañana funde, según me 
avisa don Febronio. Si le salen bien pienso darle una gratificación, pues lo ha hecho con gran empeño, ha de haber tenido que velar, y es muy buen sirviente.

El chiflón se compuso, porque me pegué a él, y convencí a Bolland de que podía levantarse. Me instalé allí, y el mismo Bolland hizo la operación en menos de media hora sin necesitar deun solo peón: todo se redujo a apretar cuatro tuercas. Lo de corregir los cubos dela rueda en vez de levantar el chiflón fue como el que mandó mudar la chimenea a otra parte porque le daba mucho calor, en vez de retirar un poco su sillón. Así se lo encajé a Bolland, y no le agradó mucho. En fin, salimos de ésa a poca costa, aunque salí ganando un dolor de espinazo por haberme estado allá arriba una hora hecho una $\&{ }^{22}$

El enojo de don Joaquín lo originaba la urgencia de continuar a la brevedad con la fabricación de azúcar, de otra manera no podrían alcanzar las metas de producción que se habían fijado para ese año de 1878, en el cual la producción de panes de azúcar en la hacienda de Tenango fue de aproximadamente 42 ooo y en la de Santa Clara de 34 000. Dos años más tarde, 1880, estimaron producir 60000 y 38 000, respectivamente. En 1883, la meta era alcanzar los 70000 panes en Tenango y 60000 en Santa Clara, manteniéndose en los primeros lugares de producción dentro de un promedio de 30 haciendas existentes en el estado de Morelos. ${ }^{23}$ Cabe señalar que estas metas no siempre se alcanzaron, ya que intervenían imponderables como las sequías, lluvias extraordinarias o bien otros factores,

22 Carta de Joaquín García Icazbalceta a Luis García Pimentel, Santa Clara, 11 de enero de 1878, en Cartas de las haciendas..., n. 23.

23 Existen algunas estadísticas para años anteriores; por ejemplo, en 1850, Tenango y Santa Clara registraron una producción de 25000 arrobas de azúcar, se puede decir que estaban en el segundo grupo en cuanto a producción, superándolas San Carlos con 45000 y Cuahuixtla y Tenextepango con 30000 . Hacia 1870, la producción de Santa Clara, posiblemente unida con la de Tenango, ascendió a 155000 arrobas, en tanto que San Carlos continuó con 45000 y Cuahuixtla aumentó a 42000 . De años posteriores únicamente se tienen datos de la hacienda de Atlacomulco, que podemos comparar con Tenango: en 1878 Atlacomulco produjo 42000 panes lo mismo que Tenango; en 1880 Atlacomulco, 42511 , y Tenango aumentó a casi 60000 , y en 1883 Atlacomulco solamente registró 30691 panes y Tenango se acercó a los 70000 . Horacio Crespo y Enrique Vega Villanueva, Estadísticas históricas del azúcar en México, México, Azúcar, S. A. de C. V., 1988, 823 p., p. 69-70. 
como la influenza en 1892 que ocasionó un número considerable de bajas entre los trabajadores.

Otro caso dela participación de un profesionista en las haciendas está ligado a la preocupación de don Joaquín ante lo incierto del devenir de la exportación de azúcar, valiosa alternativa que les permitía sacar la producción excedente y les evitaba el costo de almacenar productos. ${ }^{24}$ Ante esa incertidumbre planteó a su hermano Lorenzo y a su hijo Luis la conveniencia de reorganizar los espacios y procesos de producción, tal como ampliar las instalaciones, incluidas bodegas, para en caso de una disminución de la exportación de mascabado a Europa, o frente a alzas y bajas de los precios del mercado interno, estuvieran en posibilidades de almacenar algo de azúcar y mieles. Con toda claridad les expuso la situación, sus argumentos y estrategias para llevar a cabo los cambios. En esa ocasión manifestó a su hijo la conveniencia de aprovechar las buenas condiciones que había en la hacienda de Tenango:

[...] ahora que están buenas las mieles, [debemos] hacer mascabado, sin atropellos, sino poco a poco, de manera que no nos falten mieles para fábrica y ventas, ni se aglomere tanto trabajo que perjudique a la economía y limpieza. Aquí [en Santa Clara], a su tiempo, dar todo su vuelo a las centrífugas. Si el polvo de ellas llega a servir para fondos, tanto mejor, y si no, se exportará con más ventaja, porque, como sabes,

24 La azúcar blanca de primera que se producía en México se destinaba al consumo interno. Por lo general, estos panes de azúcar de un peso aproximado de entre 9 y $10 \mathrm{k}$ se envolvían en papel barato para evitar que se rompieran y así se comercializaban a un mejor precio. Los hermanos García Icazbalceta, además, exportaban azúcar de segunda, mascabada, producto de la miel de purga, la cual internamente se vendía con dificultad. Por un tiempo exportaron esa azúcar hacia el puerto de Liverpool, Inglaterra, en donde se la pagaban a 50 centavos por arroba, a precio de fábrica y libre de derechos, además de que el flete por el vapor hacia ese destino era más económico que a otras partes de Europa. A fines de diciembre de 1875 , experimentaron con el mercado francés sin tener buenos resultados, pues enviaron 242 sacos de azúcar, mismos que importaron la cantidad de 4039.90 francos, con lo cual el precio de la arroba de azúcar vendida en fábrica era de 22.25 centavos; a esto se sumaba que los trasatlánticos franceses eran muy caros y los buques de vela no aceptaban cargar grandes cantidades. Por ello, Joaquín García Icazbalceta aseguraba a A. Donnamette, comisionista en París, que en tales circunstancias y con esos precios, la exportación hacia Francia les significaba pérdidas y preferían el mercado de Liverpool. Carta de Joaquín García Icazbalceta a A. Donnamette, México, 30 de diciembre de 1875, BCCIB. 
cuesta menos que el de Tenango, no ocasiona rotura de formas, ${ }^{25} \mathrm{y}$ por su color más claro, se vende siempre con más estimación. De la manera que te propongo, se podrá hacer una exportación moderada que nos dé salida al exceso de mieles, lograremos una realización en Europa, y no nos expondremos a una gran pérdida. Se evitará también una excesiva aglomeración de miel en los tanques, y su descomposición consiguiente. Además, dejaremos la extracción del mascabado para hacerla poco a poco, cuando se consiga mejor flete o se entretenga con él a los arrieros; y así, aun en el caso de una alza inesperada en las mieles, estaremos en disposición de volver el de Tenango a las tinas, si así nos conviene. Lo que te digo está relacionado con el arreglo de la fábrica. ${ }^{26}$

Entre otras cosas planeaba sustituir los alambiques gastados por unos nuevos, pero dudaba de mandarlos fabricar a la Cobrería de San Juan de Letrán, en la ciudad de México, propiedad de los franceses A. Barthez y Julio Neveu porque, si bien hacían buenos trabajos y estaban bien preparados, tenían el inconveniente de ser "careros". La fábrica mencionada se anunciaba como especialista en la "construcción completa de los aparatos para la fabricación del azúcar y toda clase de alambiques destilatorios, sea por vapor o por fuego directo". Un detalle importante que los dueños del negocio hacían notar a sus clientes era la existencia de un grupo de corresponsales en los mejores talleres de Europa; además, ellos mismos habían viajado al viejo continente para conocer más de cerca los detalles de su especialidad y de esta forma estar a la altura de los muchos adelantos que estaban surgiendo en el ramo. ${ }^{27}$

25 Formas: moldes de barro para la elaboración de los panes de azúcar. Por su forma cónica servían para purgar los panes; de esta operación dependía, en parte, que disminuyeran las manchas interiores, claras u oscuras, de éstos. Beatriz Scharrer Tamm, Azúcar y trabajo. Tecnología de los siglos XVII y XVIII en el actual estado de Morelos, México, Centro de Investigaciones y Estudios Superiores en Antropología Social/Instituto Cultural de Morelos/Miguel Ángel Porrúa, 1997, p. 199.

26 Carta de Joaquín García Icazbalceta a Luis García Pimentel, Santa Clara, 2 de enero de 1878, en Cartas de las haciendas..., n. 14.

27 A. Barthez y Julio Neveu eran dueños de la Cobrería de San Juan de Letrán, negocio ubicado en la calle de San Juan de Letrán 12, según registra el Directorio del comercio del Imperio Mexicano para el año de 1867, México, Eugenio Maillefert, 1867, p. 211 (anuncio) y 258. De 


\section{La presencia de especialistas franceses}

Don Joaquín pensó durante algún tiempo la estrategia a seguir para su plan de modificar los espacios, seguramente la discutió varias veces con Luis y Lorenzo, y al fin se decidió llevarlo a cabo. Dejaron en un segundo plano los altos costos y dieron prioridad a la experiencia y preparación de los técnicos. Por ello contrataron los servicios de Barthez para realizar la compostura del alambique grande y otras cosas. "El Tigre" lo llevó a tierra caliente, en donde pasó cuando menos los meses de enero y febrero de 1880 tomando medidas, proyectando la arquería, el puente y el aparato de vapor para la hacienda de Tenango. Don Joaquín empleaba a Barthez en todo cuanto podía, le encargó instalar una gran báscula, cuya principal dificultad en la instalación estaba en que debía colocarse a "metro y medio de profundidad, para que [... pudiera entrar] un hombre por debajo", pero la dureza del suelo complicaba la excavación.

Barthez también hizo el bosquejo para cambiar la bóveda de la casa de calderas de la hacienda de Santa Clara, obra que inicialmente realizó con la ayuda de un albañil y un peón traído desde la ciudad de México. Lo más conveniente, decía don Joaquín, era contratar a los ayudantes de fuera "porque trabajaban mejor y no cobraban tan caro". En caso de necesitar más personal, Barthez y su equipo capacitaban a los locales. Esta obra ofrecía no pocas dificultades porque se trataba de derribar las dos bóvedas atravesadas de la casa de calderas y sustituirlas con la prolongación de la bóveda principal.

"El Tigre" era consciente de que la magnitud de la obra "escandalizaría" sobre todo a su hermano, pero siempre la consideró muy necesaria para poder colocar el nuevo aparato. Con su acostumbrada claridad expuso los argumentos estéticos, técnicos y económicos para la ejecución de las modificaciones en Santa Clara, insistiendo en que:

Esas bóvedas [existentes] desfiguran la casa, la ahogan, estorban para todos los trabajos, y hacen imposible la vigilancia. El aparato nunca

acuerdo con el censo de 1882, cuya información nos proporcionó la historiadora Dolores Morales, el francés Julio Neveu, de 44 años, casado, vivía en la calle de Santa Brígida Poniente número 11 y en la parte baja tenía su taller. 
quedará bien con ellas, y aun cuando no se ponga, debe regularizarse esta hermosa casa, que ganará muchísimo. Están tomadas las medidas, y la cosa no es tan grave como parece. Se necesitan de 6 a 7 mil ladrillones: ahora se pagan a 30 pesos pero se han ajustado con el formero a 25, y he contratado otros en Jonacate [Jonacatepec] a 20. La cal es barata. La cimbra se facilita mucho, porque se pone sobre las bóvedas actuales antes de derribarlas: (sabes que son mucho más bajas), y así tampoco queda nunca descubierta la casa. Tengo empeño en esta obra, que por supuesto se hará en la parada, y ahora no se hará más que preparar los materiales. Quedará una casa como quizá no habrá otra. Calculo el costo en unos 800 pesos y vale la pena de gastarlos para regularizar de una vez esa oficina tan importante, y hoy tan fea e incómoda para todo. ${ }^{28}$

Por otra parte, en Tenango, Barthez ya había cambiado el arco de la entrada y lo había hecho muy bien, así que don Joaquín aprovechó estas aptitudes y le encargó el proyecto del acueducto de Santa Clara, ${ }^{29}$ pero además quería dedicar la estancia de Barthez ahí para emprender otra obra de gran importancia y costo, como era cambiar la caldera para el cocimiento de la miel. Por la magnitud del proyecto, primero hizo consultas con el administrador de la hacienda de Santa Bárbara Calderón, en donde habían experimentado algo semejante. Después la discusión siguió entre don Joaquín, el administrador de Santa Clara y el propio Barthez. Con toda la información posible, les planteó a Luis y a Lorenzo la conveniencia de iniciar esta otra obra que, si bien era costosa, a la larga les produciría considerables economías.

Aunque prefería tratar estos asuntos personalmente, la premura lo obligó a valerse de las misivas, ya que si se decidía la colocación del aparato, podría arreglar ciertos pormenores estando él en las haciendas; de otra manera se complicarían las cosas. El punto principal era este: ¿conviene

28 Carta de Joaquín García Icazbalceta a Luis García Pimentel, Santa Clara, 4 de febrero de 1880, en Cartas de las haciendas..., n. 119. Jonacate era la manera familiar de llamar al pueblo de Jonacatepec.

29 Cartas de Joaquín García Icazbalceta a Luis García Pimentel, de enero y febrero de 1880, en Cartas de las haciendas..., n. 97, 101, 102, 105, 117, 119, 126-128. 
más emplear veinticinco mil pesos en esta mejora, o destinarlos a pagar una deuda? Si bien lo primero significaba un gran desembolso, a la larga disminuirían gastos de suministros, honorarios de operarios y costos con la fabricación local de aparatos; además esperaban elevar cuando menos un $10 \%$ o más la producción y mejorar la calidad de sus productos, por lo que debía considerarse más que gasto como una inversión productiva. Para facilitar la toma de decisión, Joaquín García Icazbalceta presentó claramente a su hijo las ventajas y desventajas del asunto:

Digo que es el punto principal, porque si no tuviéramos pasivo, yo no dudaría un momento en poner el aparato.

Las ventajas que procuramos son: excusar el gasto de leña, que importa cada año unos \$2500; disminuir unos 35 o 40 pesos semanarios el gasto de hornalleros y caldereros: obtener un aumento en la cantidad de azúcar y una mejora en la clase. ${ }^{30}$ Según don Gregorio, todo esto obtienen en [la hacienda de] Calderón: calculan allí el aumento en 10\%, y en cuanto a la clase, dice don Gregorio que está muy buena y pareja: hacen también una cantidad considerable de azúcar de miel de barrillos.

Inconvenientes: el mayor de todos es el gasto, que no puede bajar de 25 ooo. El segundo, el mucho trabajo que nos va a dar. No me ocurre otro.

Como sucede siempre que se vacila en un negocio, he querido diferir este, y dejarlo para más adelante, pero tropiezo con dos circunstancias que me lo impiden: 1o. que los actuales generadores [se] están acabando, y como no podemos pasarnos sin ellos, es muy triste hacer un gasto para quedarnos como estamos, con nuestra leña y demás; 2o. que en la actualidad tenemos aquí a Barthez, quien puede hacernos el aparato con una grandísima economía. Esto es muy de considerar, y para que lo calcules, te diré solamente que por boca del mismo Barthez he

30 Como ya se dijo, cada año se planeaba aumentar la producción de panes de azúcar y mejorar su calidad, sobre todo, obtener más blancura y dulzor. Por ejemplo, en dos años, de 1878 a 1880, aumentaron de 42000 a 60000 panes en la hacienda de Tenango, y en Santa Clara de 34000 a 38000 , pues esta hacienda producía menos. Para 1883, la meta era alcanzar los 70000 panes en Tenango y 60000 en Santa Clara. Siempre y cuando los factores meteorológicos y de personal lo permitieran. 
sabido que los cristalizadores que nos costaron tres mil pesos les salieron a ellos en mil y quinientos, es decir, que nos costaron el doble. Considera lo que sería en un aparato entero hecho en cobrería.

Estoy bien fatigado de pensar en este negocio del aparato, y no acabo de resolverme. Resuélvanlo entre tú y Lorenzo. Si opinan que no, ya no pensaré más; si dicen que sí, me ocuparé, antes de irme, en arreglar cuantos pormenores me ocurran y con cuanto esmero pueda. Desde luego habría que encargar los generadores [a Europa] y pagarlos con el mascabado necesario [destinado a la exportación]. El resto se iría haciendo poco a poco en el resto de este año y la mitad del venidero. ${ }^{31}$

\section{Un ingeniero alemán en las haciendas}

En este constante mantenimiento de la maquinaria, a principios de 1890, encontramos la presencia de un técnico de origen alemán, posiblemente ingeniero, de nombre J uan Schliemann. En septiembre de ese año, pasó una temporada en la hacienda de Santa Clara revisando el funcionamiento de los moledores de caña y la marcha de todas las máquinas de la casa de calderas: los depósitos de miel, las defecadoras, ${ }^{32}$ las evaporadoras, ${ }^{33}$ los tachos, ${ }^{34}$ los condensadores y las centrífugas; también revisó los trabajos de albañilería, herrería o plomería que con anterioridad había encargado a los administradores.

Dos años antes, Schliemann había pasado algunos días en las haciendas encargado, entre otras cosas, de acondicionar la nueva maquinaria de

31 Carta de Joaquín García Icazbalceta a Luis García Pimentel, Santa Clara, 15 de febrero de 1880, en Cartas de las haciendas..., n. 129.

32 En las defecadoras se realizaba la operación conocida como "defecación”, por medio de la cual se eliminaban las sustancias en suspensión y disolución presentes en el guarapo. Como agente defecante se utilizaba la lejía de cenizas, después el agente alcalino utilizado fue el alumbre y ácido sulfúrico, y finalmente se generalizó el uso de la cal. Crespo, Modernización y conflicto social..., p. 176-177.

33 Después de la defecación, el guarapo o jugo de caña, se transportaba a las pailas evaporadoras, donde se sometía el jugo a calor moderado para que subieran a la superficie las impurezas o cachazas; cuando soltaba las primeras espumas se aumentaba el calor y se agregaba nuevamente la cal, hasta que la espuma fuera totalmente blanca y se eliminaban las impurezas, entonces quedaba el caldo "clarificado". Ibidem, p. 177.

34 Tachos, pequeñas calderas de cobre en donde se ponía la meladura a fuego intenso hasta que se formaran los granos de azúcar. Scharrer, Azúcar y trabajo..., p. 201. 
la hacienda de Tenango. En estas temporadas Schliemann ajustaba los aparatos y se cercioraba de que los operarios de la hacienda siguieran las instrucciones de manejo. En todo caso, les señalaba las fallas en la operación que habían provocado los desajustes y realizaba las composturas. Informaba detalladamente por escrito a don Joaquín y daba nuevas instrucciones para que los administradores de las haciendas las pusieran en práctica.

Estas revisiones periódicas y medidas preventivas para evitar en lo posible alguna interrupción en el proceso de producción, las dejaba don Joaquín generalmente en manos de personal especializado, que además se caracterizaba por ser de origen extranjero, tal vez porque consideraba que tenía mejor preparación, mayor experiencia y, por lo mismo, estaría al tanto de las novedades en el ramo que llegaban de Europa o Estados Unidos, aunque esto le significara pagar un salario más alto. Emplear personal con esta característica fue algo recurrente en las fincas, particularmente en esta intensa etapa modernizadora.

\section{Los arquitectos-ingenieros Hidalga en las haciendas}

Un ejemplo más de la presencia de profesionistas en las fincas azucareras es la participación de los propios sobrinos delos hermanos García Icazbalceta, quienes para mayor seguridad en cuanto a la ejecución de obras de ingeniería y arquitectura en las haciendas pedían asesoría a sus sobrinos Ignacio y Eusebio Hidalga, hijos de su hermana Ana y del reconocido arquitecto Lorenzo Hidalga. A ellos, además de enviarles todos los proyectos para su revisión y visto bueno, los contrataron para diversas obras y operaciones. Todo parece indicar que esta parte de la familia desempeñó un importante papel en el conocimiento y las mejoras llevadas a cabo en las haciendas de Tenango y Santa Clara, por lo que vale la pena detenerse un poco en algunos datos de estos personajes.

Lorenzo Hidalga y Musitu nació en el pueblo llamado Maestu, cercano a Vitoria, en la provincia deÁlava, en el norte de España. Sus padres fueron Francisco Hidalga y Manuela Musitu. ${ }^{35}$ Por el lado materno tenía vínculos 
familiares con Ana Ramona de Icazbalceta y Musitu, madre de los hermanos García Icazbalceta. El arquitecto Hidalga estudió en la Academia de Bellas Artes de San Fernando de Madrid, donde obtuvo el título de arquitecto en 1836. Poco después pasó a vivir a París. Ahí trabajó en el taller del notable arquitecto Henri Labrouste (1801-1875), quien tiene entre sus obras más importantes la Biblioteca de Santa Genoveva y remodelaciones en la Biblioteca Nacional de Francia. ${ }^{36} \mathrm{El}$ joven arquitecto también tuvo una buena amistad con Eugène-Emmanuel Viollet-le-Duc (1814-1879), ${ }^{37}$ integrante del mismo taller, establecido en 1830 y pronto reconocido como representante de la corriente romántica o racionalista.

Además, la estancia parisina del arquitecto Lorenzo Hidalga quedó fuertemente señalada por la influencia que dejaron en él los conocimientos de otros dos arquitectos franceses que habían destacado años antes: JeanNicolas-Louis Durand (1760-1832), en su tiempo profesor de la Escuela Politécnica, y Claude Nicolas Lédoux (1736-1806), autor del libro La arquitectura considerada en relación con el arte, las costumbres y la legislación, publicado en 1808. Este último texto modificó los criterios arquitectónicos de la tradición clásica al proponer como principios constructivos

desmantelamiento del baldaquino de Lorenzo Hidalga (1810-1872)", Boletín de Monumentos Históricos, tercera época, n. 15, enero-abril 2009, p. 85-112.

36 Henri Labrouste (1801-1875) nació y murió en París. Estudió arquitectura en la prestigiosa Escuela de Bellas Artes de la capital francesa, y gracias a que ganó la apreciable beca de la Academia en Roma pudo vivir durante seis años en esa ciudad. A su regreso a París estableció su taller y rápidamente destacó entre la corriente de los racionalistas. A Labrouste se le considera parte del grupo de los artífices de la transición arquitectónica entre el estilo neoclásico hacia las formas inspiradas en los estilos históricos y el racionalismo austero de la arquitectura moderna. Fue pionero en el empleo de las estructuras de hierro.

37 Eugène-Emmanuel Viollet-le-Duc (1814-1879) fue arquitecto, arqueólogo y escritor. Representa una de las más importantes figuras de la escuela racionalista francesa, que rechazó la enseñanza de la Escuela de Bellas Artes, sustituyéndola por la práctica y los viajes por Francia e Italia. Se dedicó principalmente a la restauración e invención de conjuntos monumentales medievales como la Cité de Carcasona y el Castillo de Roquetaillade. Fue muy criticado por el atrevimiento de sus soluciones y añadidos no históricos, y la pérdida de autenticidad de muchos monumentos. Sus restauraciones buscaron más que recuperar, mejorar el estado original del edificio, con un interés centrado más en la estructura y en la propia arquitectura que en los elementos decorativos (disponible en: http://es.wikipedia. org/wiki/Eug\%C3\%A8ne_Viollet-le-Duc, 15 de marzo de 2013). 
la solidez, la salubridad, la comodidad y la economía. Ambos arquitectos fueron considerados precursores de una arquitectura funcionalista. ${ }^{38}$

Lorenzo Hidalga tuvo intenciones de seguir preparándose en Italia, conforme al testimonio de Manuel Francisco Álvarez, ${ }^{39}$ uno de los compañeros de sus hijos en la Academia de San Carlos, pero el compromiso que tenía con sus parientes en México, quienes "influyeron para sus estudios de arquitecto, con objeto de que aquí fueran útiles” lo inclinaron a emprender su viaje a Veracruz. Llegaría a la ciudad de México el 21 de mayo de 1838.

De acuerdo con los datos proporcionados por el arquitecto Israel Katzman, ${ }^{40}$ un año después de su llegada al país Lorenzo Hidalga construyó o tal vez remodeló por completo la iglesia de la hacienda de Santa Clara, propiedad de sus parientes García Icazbalceta. ${ }^{41}$ En 1840, se casó con Ana García Icazbalceta (1814-1888), segunda hija de Eusebio García y Ana Ramona de Icazbalceta. Tuvieron cinco hijos: dos mujeres, Loreto y Pilar, y tres hombres, Ignacio, Eusebio y Federico (este último falleció muy pequeño).

El trabajo de Lorenzo Hidalga pronto tuvo una amplia aceptación. Entre sus obras más reconocidas están la construcción del mercado de El Volador y del Teatro Santa Anna o Gran Teatro Nacional (1841-1844). Es importante señalar que el arquitecto Hidalga gustaba de redactar grandes explicaciones para justificar sus proyectos, y gracias a ellas, hoy sabemos que, siguiendo a sus maestros franceses, para él todos los edificios sobresalientes se habían construido aplicando los principios generales de "la conveniencia y de la economía”. Entendiendo que la conveniencia en un edificio "consiste en la solidez, salubridad y comodidad" del mismo. En

38 Elisa García Barragán, “El arquitecto Lorenzo de la Hidalga”, Anales del Instituto de Investigaciones Estéticas, n. 80, primavera de 2002, v. XXIV, p. 101-128, y de la misma autora, “Lorenzo de la Hidalga: un precursor del funcionalismo", Anales del Instituto de Investigaciones Estéticas, n. 48, 1987, p. 71-88.

39 Manuel Francisco Álvarez, El doctor Cavallari y la carrera de ingeniero civil en México, México, Imprenta A. Carranza, 1906, p. 81-82.

40 Israel Katzman, Arquitectura del siglo XIX en México, México, Trillas, 1993, 397 p.

41 Desde épocas anteriores las tres haciendas de la familia García Icazbalceta tuvieron capilla, a cada una asistía periódicamente el cura a dar misa. Los propietarios se preocuparon por su constante mantenimiento y ornamentación. Es muy probable que la hacienda de Santa Clara ya contara con una capilla más pequeña y el arquitecto Hidalga se encargara de su remodelación, para convertirla en una iglesia de mayores proporciones y solidez. 
tanto que por economía arquitectónica Hidalga entendía "el proscribir en un edificio todo lo que sea inútil”. Por consiguiente, sería "tanto más económico un proyecto cuanto más simétrico, más regular, más sencillo”. ${ }^{42}$ Estos principios aplicados por el arquitecto Hidalga seguramente coincidieron con los gustos casi siempre austeros de su sobrino y a la vez hermano político Joaquín García Icazbalceta, según se aprecia en la sólida y sobria construcción de la iglesia de la hacienda de Santa Clara, a diferencia del estilo barroco de la de Tenango, con su cúpula recubierta de talavera. ${ }^{43}$

Por su parte, los dos hijos varones de Lorenzo Hidalga, es decir Ignacio (1841-?) y Eusebio (1845-1893) Hidalga García, como ya se dijo, estudiaron en la Academia de San Carlos, en donde primero obtuvieron el título de "ingenieros topógrafos e hidromensores" y después, entre 1861 y 1863 respectivamente, el de arquitectos e ingenieros civiles. ${ }^{44}$ Un dato a señalar es el hecho de haber sido alumnos de Javier Cavallari (1811-¿ं?), ${ }^{45}$ profesor italiano contratado por la Academia para reorganizar el plan de estudios que cursaban los estudiantes de la carrera de arquitectura, con el objetivo de cubrir las expectativas y necesidades de construcciones de nuevo tipo, así como las exigencias cada vez más fuertes de desarrollar nuevas ideas y proyectos con el propósito de tener un urbanismo diferente. Para el investigador Eduardo Báez Macías, fue Javier Cavallari quien "hizo posible el gran salto de la arquitectura de albañilería a la arquitectura de las grandes estructuras metálicas", con lo que se rompe la vieja tra-

42 Ibidem, p. 234.

43 A principios del siglo XIX, esta iglesia era considerada una de las más ricas en ornamentación, con "grandes retablos barrocos y policromados, tanto en el altar mayor como en los del crucero y en los laterales”. Véase Alfonso Toussaint, “Ubicación y descripción arquitectónica de las haciendas. Relación y breve reseña de las haciendas de Morelos", en Brígida von Mentz, Beatriz Scharrer et al., Haciendas de Morelos, p. 351, quien cita a Manuel Romero de Terreros, Antiguas haciendas de México, México, Patria, 1956, p. 263.

44 "Documentos relativos al examen profesional de ingeniero civil y arquitecto del alumno Eusebio Hidalga..., noviembre de 1863" e "Ignacio Hidalga solicita examen para obtener el grado de ingeniero topógrafo e hidromensor, junio 27 de 1860", Archivo de la Antigua Academia de San Carlos, n. 5785 y 6255, respectivamente. Eduardo Báez Macías, Guía del Archivo de la Antigua Academia de San Carlos, 1844-1867, México, Universidad Nacional Autónoma de México, Instituto de Investigaciones Estéticas, 1976, 438 p.

45 Javier Cavallari (1811-¿?) fue profesor de la Universidad de Palermo altamente reconocido por sus conocimientos en ingeniería, socio del Instituto Real de Arquitectos Británicos, doctor del cuerpo académico de Gotinga. Estuvo en México de 1857 a 1864. 
dición de la construcción basada en la mampostería y la cantera. Con Cavallari los alumnos de la Academia aprendieron a diseñar mercados, terminales de ferrocarril, almacenes, auditorios, caminos de fierro, puentes y canales, etcétera. ${ }^{46}$ Este fue el ambiente en el que se formaron profesionalmente Eusebio e Ignacio Hidalga, sobrinos de los García Icazbalceta.

De acuerdo con los datos que registró su compañero Manuel Francisco Álvarez, los hermanos Hidalga estuvieron más orientados hacia las obras particulares. Por un tiempo, Ignacio se ocupó en levantar planos de haciendas y en realizar obras en el estado de Michoacán, junto con su compañeroJ osé Ramón Ibarrola. ${ }^{47}$ En cambio, a Eusebio se le reconocía como muy buen estudiantey, sobre todo, excelente calculista. Un año antes de obtener su título ganó un reconocimiento por la elaboración del "Proyecto para un viaducto". En 1888, fue nombrado académico correspondiente en la ciudad de México de la Real Academia de Bellas Artes de San Fernando de la ciudad de Madrid. ${ }^{48}$

Más tarde, en 1888, fueron los hermanos Hidalga los que proyectaron y dirigieron la construcción del edificio de cinco pisos que albergó la famosa tienda departamental El Palacio de Hierro, primer edificio de la ciudad de México en utilizar estructuras de acero y combinarlas con cristales, concluido a mediados de $1891 .{ }^{49}$

46 El nuevo plan llamado "Cavallari" fue la base para la arquitectura de la segunda mitad del siglo XIX, la carrera duraba siete años y el título que se otorgaba era el de arquitecto e ingeniero civil. A las materias que ya cursaban, como Explicación de los Órdenes Clásicos, Copia de Monumentos y Composición, le agregaron Física, Química Inorgánica, Dibujo de Maquinaria, Mecánica Aplicada, Construcción de Puentes, Canales y Obras Hidráulicas, Caminos de Fierro e Historia de la Arquitectura. Además, se reforzaron las matemáticas al añadir Cálculo Diferencial e Integral a Trigonometría y Geometría Analítica. Eduardo Báez Macías, Historia de la Escuela Nacional de Bellas Artes: Antigua Academia de San Carlos, 1781-1910, México, Universidad Nacional Autónoma de México, Escuela Nacional de Artes Plásticas, c. 2008, 309 p., p., 165-167.

47 José Ramón Ibarrola ingresó a la Academia de San Carlos con el título de hidroagrimensor que obtuvo en 1859 en la Escuela de Agricultura. Fue conocido por la buena presentación de los planos de haciendas que realizó, ya por sus dibujos como por el gusto y perfección de sus letreros. Manuel Francisco Álvarez, El doctor Cavallari..., p. 35.

48 Disponible en : http//www.realacademiadebellasartesanfernando.com/assets/docs/academicos/relacion_general_de_academicos.

49 Patricia Martínez Gutiérrez, El Palacio de Hierro: arranque de la modernidad arquitectónica en la ciudad de México, México, Universidad Nacional Autónoma de México, Facultad de Arquitectura, Instituto de Investigaciones Estéticas, 2005, 159 p., p. 49-50, 57-59. 
Ignacio y Eusebio Hidalga ya se habían ganado especialmente el reconocimiento y la confianza de sus tíos García Icazbalceta. A Ignacio, su tío Joaquín, con la anuencia de sus hermanos José Mariano y Lorenzo, en virtud de que reunía tres importantes requisitos pues era "honrado, de la familia e inteligente”, le encomendó desde abril de 1869 la administración de su hacienda cerealera denominada El Mayorazgo (ubicada en el distrito de Lerma, Estado de México), ya que con la muerte de su hermano Tomás (1816-1868) los García Icazbalceta no se daban abasto para atenderla debido a que las fincas azucareras absorbían todo su tiempo y esfuerzo. Esta fue la razón principal por la que más tarde decidieron venderla. Sin embargo, ante la dificultad de encontrar un comprador para esta hacienda, Lorenzo y Joaquín se vieron en la necesidad de venderla en fracciones; para ello nombraron en su representación a sus sobrinos Ignacio y Eusebio, quienes tenían experiencia en avalúo de terrenos y recibirían una comisión por encargarse de la venta de tierras de El Mayorazgo. ${ }^{50}$ Para cada porción que se vendía, Ignacio Hidalga elaboraba el respectivo plano.

En particular, don Joaquín recurría constantemente a los conocimientos y experiencia de sus sobrinos Hidalga para resolver cuestiones muy particulares en sus haciendas azucareras, tales como rectificar las medidas para la caja de agua de Jantetelco, que surtía a las haciendas, antes de enviarlas a fabricar con el herrero, ${ }^{51}$ o revisar el diseño de la arquería del acueducto de la hacienda de Tenango para comprobar los niveles y medidas. ${ }^{52}$

Por su parte, Ignacio debía revisar el proyecto del acueducto que había realizado Barthez para que dijera si "la obra tiene la solidez necesaria". ${ }^{53}$ El mismo Ignacio ayudó a su tío a recordar cómo se calculaba "la capacidad de las medias esferas de las defecadoras", pues lo había olvidado y lo necesitaba para poder fijar las dimensiones de las calderas, que era "cosa tan difícil como delicada, y de que depende todo”, le urgió don Joaquín. ${ }^{54}$

$\mathrm{Si}$ bien consultaba casi todas sus dudas con Eusebio o Ignacio, para algunas cuestiones en particular acudía a Ignacio "porque reúne la agricul- 
tura y la arquitectura", y aun cuando Ignacio estaba tan ocupado con la venta de El Mayorazgo, su tío requería también su intervención en las fincas azucareras, pues en Tenango habían comenzado a trabajar en la arquería y era imprescindible su opinión en lo relativo a los cimientos de dicha arquería y también para elegir el arado. ${ }^{55}$

Tener esta asesoría de profesionistas altamente calificados, como sus sobrinos, significaba a veces desembolsos costosos para los hermanos García Icazbalceta. Por su parte, Joaquín estaba dispuesto a pagarlos en beneficio de las obras pero a Lorenzo le parecía que los honorarios que cobraba Eusebio por encargarse de los cimientos del río eran muy altos; no obstante, la mayoría de las obras importantes llevadas a cabo en las fincas azucareras tuvieron, al menos, el visto bueno de los hermanos Hidalga. ${ }^{56}$

\section{Otros prácticos y profesionistas}

Continuamente se hacían cambios, composturas y ajustes que exigían los acelerados ritmos de trabajo en estas productivas fincas, cuya meta de producción era aumentar el número de panes de azúcar año con año; deahí la necesidad de contratar los servicios de otros prácticos y profesionistas en las haciendas de la compañía García Icazbalceta Hermanos, para prevenir cualquier contratiempo en las distintas áreas de producción o en su caso atender las emergencias para evitar parar la producción.

Los periodos de mayor actividad eran los dela molienda y elaboración del azúcar que se llevaba a cabo los primeros meses del año; por eso la estancia de don Joaquín en las fincas era precisamente entre enero y marzo; salvo que ocurriera alguna eventualidad, iba de nuevo en los meses siguientes. Poco a poco fue involucrando a su hijo Luis en las actividades de las haciendas y lo responsabilizó de ir antes de que terminara el año, entre noviembre y diciembre, y a veces desde septiembre, para supervisar los campos de caña y la cosecha.

No obstante, en los meses intermedios la supervisión de las haciendas quedaba en manos de los imprescindibles administradores. Por lo general eran dependientes bien calificados, personas experimentadas en labores 
del campo y manejo de personal. En cada hacienda había un administrador, se les dejaba la responsabilidad del cultivo de la caña (casi siempre bajo la supervisión de don Joaquín o de Luis), hacían ajustes en cuanto a las técnicas e instrumentos de cultivo y de riego. Los meses restantes del año mantenían informado a su patrón de su funcionamiento, de las condiciones del campo, del personal, del apero y maquinaria, de los animales de trabajo, de los acontecimientos políticos de la región y, en general, de la vida cotidiana en las fincas, ya fuera por carta o personalmente en la ciudad de México.

Nos faltan datos para confirmar que se trataba de personal con estudios profesionales, lo que se observa es que debían ser individuos que supieran leer y escribir, también llevar la contabilidad de los diferentes quehaceres en las haciendas, saber manejar a los distintos dependientes y peones, pero sobre todo debían tener experiencia en “criar caña” y conocimientos en el proceso de elaboración de azúcar para poder supervisar las labores. El requisito fundamental que debían cubrir los administradores ante los dueños dela compañía García Icazbalceta Hermanos era, primero que nada, ser personas honestas, trabajadoras y de toda su confianza, pues en ellos recaía la mayor responsabilidad del manejo de las fincas, principalmente cuando los propietarios estaban ausentes.

En las "Cartas de las haciendas" de don Joaquín a su hijo, existen algunos datos breves de otros prácticos y profesionistas empleados en las haciendas de los García Icazbalceta. Por ejemplo, a principios de 1880, llamaron al maquinista Onesiphor Lebesque para la cotización de la instalación de algunos pararrayos pero, como éste estaba muy ocupado y no pudo acudir rápidamente, contrataron a otro práctico que instaló 15 pararrayos: cinco en Santa Clara, siete en Tenango y tres en San Ignacio, la hacienda más pequeña. Aunque el costo de esta instalación ascendía a 1025 pesos (sin incluir la comida del pararrayista y el sueldo de los peones que le ayudaban), se consideró un gasto necesario porque de esta manera quedaban protegidos todas las oficinas, el chacuaco, las iglesias de cada una de las haciendas y, sobre todo, los dependientes. Como de costumbre, don Joaquín intentó negociar el mejor precio con el pararrayista:

Le ofrezco mil pesos por los 15 pararrayos, y él quiere 1025 , siendo de nuestra cuenta los peones y la comida de él. De todos modos he 
de ajustarme porque ya la estación está muy avanzada y, sobre todo, porque estando ajustados 5 [pararrayos] a 100 pesos que son 500 , me salen los otros 10 a 50 pesos. Si nos quedamos en los 5 , luego tenemos que poner los 10, y en un descuido nos cuestan 800 pesos. Mas los 5 sólo defenderían las iglesias de aquí y de Tenango, quedando expuesto lo demás, y todas las personas. Me duele este gasto lo que no puedes figurarte, y más que nada me puede pensar que tal vez Pano se enfadará; pero debes considerar que es indispensable para la seguridad de estos edificios, que valen tanto, y la de nuestros dependientes con sus familias. Todos, sin excepción, están aterrorizados con las tempestades, y no les falta razón. En composturas de los estragos hechos por los rayos, hemos gastado ya, sin duda, más de los mil pesos, y según caen (especialmente aquí), el día menos pensado nos aflojan toda una torre o la cúpula y no lo reponemos con cuatro, seis u ocho mil pesos. Ya que existe un medio de preservación, sería temeridad no aprovecharlo, haciendo un gasto por una sola vez. ${ }^{57}$

Como puede verse en el fragmento de esta carta, si bien inicialmente el hacendado buscaba economizar en la instalación de los pararrayos o en cualquier otra obra, es evidente que en muchas ocasiones prefería pagar más por asegurar calidad y actuar oportunamente para evitar percances, en todo caso tener ahorros en otras cosas.

En una posible lista de profesionistas que colaboraron en las haciendas de los García Icazbalceta, debe incluirse al médico, ${ }^{58}$ el abogado y el veterinario. A los dos primeros, don Joaquín les pagaba una iguala mensual por sus servicios. Ambos atendían las tres haciendas y apenas se daban abasto porque no faltaban incidentes. El médico no sólo atendía a los ope-

57 Carta de Joaquín García Icazbalceta a Luis García Pimentel, Santa Clara, 8 de marzo de 1880, en Cartas de las haciendas..., n. 146.

58 De acuerdo con un testimonio del propio Joaquín García Icazbalceta, no todos los hacendados se preocupaban por tener un médico que atendiera a los trabajadores. Así se lo comentó don Joaquín a su amigo el doctor Nicolás León, quien le pidió una recomendación con algún hacendado que quisiera contratarlo en su hacienda. Carta de Joaquín García Icazbalceta a Nicolás León, 9 de mayo de 1892, en Ignacio Bernal, Correspondencia de Nicolás León con Joaquín García Icazbalceta, México, Universidad Nacional Autónoma de México, Instituto de Investigaciones Antropológicas, 1982, 314 p., p. 268. 
rarios sino también a sus familiares, especialmente a las esposas de éstos en caso de parto. También acudían a él en casos de epidemias, como la de influenza que hubo en marzo de 1890, cuando enfermaron 130 trabajadores de una de las haciendas y tuvieron que suspender las labores. Por la misma causa, en 1892, murieron cerca de 200 empleados. ${ }^{59}$

Por supuesto llamaban rápidamente al médico cuando había accidentes de trabajo, muchas veces graves como el ocurrido el 26 de enero de 1879, cuando un "trapichero borracho" perdió el equilibrio y cayó a la máquina donde se molía la caña; aunque rápidamente lo auxiliaron, la pierna derecha le quedó deshecha. Inmediatamente avisaron a don Joaquín que estaba en la hacienda y mandó traer al médico Irigoyen y al padre Martínez. El médico intentó amputarle la pierna con ayuda de un "español que hace decirujano" pero el accidentado estaba muy débil y no resistió la operación. Sólo el sacerdote alcanzó a "confesarlo y olearlo" antes de morir. ${ }^{60}$

Por su parte, el abogado Robles atendía todos los pleitosjudiciales con las distintas comunidades de los doce pueblos que quedaban dentro de la jurisdicción de las haciendas de los García Icazbalceta, ${ }^{61}$ bien se tratara de tierras, aguas o pagos de contribuciones al gobierno. Para mala suerte del abogado, cuando los asuntos no se resolvían o tomaban más tiempo, le bajaban el sueldo. Esto sucedió en marzo de 1880 cuando don Joaquín aplicó esta medida y así se lo comunicó a su hijo Luis: "La razón de que Robles gane desde 1. de abril 60 pesos en vez de 80, es que le rebajé el sueldo para economizar, y por lo que se alarga el negocio de Ocuituco". 62

59 lbidem, p. 230.

60 Cartas de las haciendas..., n. 62, 26 de enero de 1879.

61 Arturo Warman refiere que los límites de las haciendas eran, al norte, Hueyapan, incluida la cumbre del Popocatépetl (en compensación se extendía hasta Puebla); al este penetraban hasta Puebla, colindaban con Matlala y Atencingo; al suroeste, hasta el cerro de las Tetillas, metido en la Sierra de Huautla (la zona de bosques y oyameles de la que se apropió la fábrica San Rafael); al oeste, Tenextepango y Coahuixtla. En su jurisdicción quedaban incluidos doce de los catorce pueblos de esta región: Tlacotepec, Zacualpan, Temoac, Huazulco, Amayuca, Jantetelco, Amacuitlapilco, Chacaltzingo, Jonacatepec, Atotonilco, Tetelilla y Telixtac. Estaban incluidos dos asentamientos: Amilcingo y Popotlán. Un rancho: Amotzongo y Copalillo. Las haciendas se extendían por cinco municipios del estado de Morelos: Zacualpan, Jantetelco, Jonacatepec, Tepalcingo y Axochiapan. Véase Arturo Warman, ... y venimos a contradecir. Los campesinos de Morelos y el Estado nacional, México, Secretaría de Educación Pública/Centro de Investigaciones y Estudios Superiores en Antropología Social, 1976, 351 p., p. 53-54.

62 Cartas de las haciendas..., n. 146, 8 de marzo de 1880. 
El negocio de Ocuituco es un tema recurrente en la correspondencia de don Joaquín con su hijo, ya que se trata del complejo y siempre vivo problema relativo al suministro de agua para las haciendas y la necesidad de este vital líquido por parte de las comunidades. En el siguiente fragmento de carta pueden observarse las órdenes que dispuso "el Tigre", tanto para uno de los administradores como para el licenciado Robles, así como el concepto que tenía de las autoridades de Cuautla de Morelos y de lo que pasaba con los pobladores del mencionado pueblo de Ocuituco:

Hoy tuve una larga conferencia con don Gregorio y Robles acerca del negocio de Ocuituco. Estos diablos no ceden, sino que siguen alborotando a todos, y oponiéndose a la limpia de los socavones. Mañana sale Robles para Morelos, con objeto de agitar la presión del ayuntamiento, que es indispensable, aunque dudo se efectúe porque el jefe político de Morelos los favorece abiertamente. El lunes volvemos a la limpia delos socavones, y si es preciso la haremos a mano armada. Me han hecho perder la paciencia, y no me pararé en nada. En el camino me apee varias veces para ver los arcos y apantle. Han hecho mal la limpia, y ya se compondrá. Reconocimos hoy los títulos que traje, y se están copiando algunos. Si el jefe de Morelos empieza con las suyas, le armo una pelotera con el gobernador. ${ }^{63}$

Esta respuesta del hacendado, de acuerdo con el historiador Horacio Crespo, se puede enmarcar en la política porfirista de fomento a la modernización agrícola, que tuvo como uno de sus elementos las concesiones de franquicias, recursos y subsidios para aquellos que invirtieran en obras significativas para el crecimiento económico. En este marco, el incremento de la infraestructura hidráulica estaba presente en las prioridades de dicho gobierno y, consecuentemente, la garantía del uso del agua fue considerada la premisa básica para tales acciones. Esto incluyó el reconocimiento de todos los títulos coloniales del usufructo del vital líquido. En el caso del "negocio de Ocuituco", el juez de Primera Instancia de Cuautla de Morelos había resuelto (el 23 de julio de 1868) el reconocimiento de validez a la concesión virreinal de 1608 otorgada a la 
hacienda de Santa Clara Montefalco sobre las aguas del río de San Pedro Mártir, del cerro de Minaltepec, en contra de las pretensiones de la comunidad de Ocuituco. ${ }^{64}$

Por otra parte, la marcha delas haciendas y todo su proceso de modernización requirió de más profesionistas y prácticos, como los maestros de las escuelas y una buena cantidad de operarios, algunos de los cuales se especializaron en cierta parte del proceso de producción de azúcar o de aguardiente, pero también en la vida cotidiana de las fincas azucareras la presencia de los curas fue necesaria.

\section{Consideraciones finales}

Como ya se mencionó, de acuerdo con varios especialistas del tema, el desarrollo tecnológico en las haciendas azucareras inició a partir de la década de 1880. Las condiciones económicas del país propiciaron que la mayoría de las haciendas, aproximadamente 30 registradas en la región, reemplazaran paulatinamente sus maquinarias y paralelamente efectuaran cambios en los distintos procesos de producción. Las haciendas propiedad de la compañía García Icazbalceta Hermanos no fueron la excepción pero además, como se ha visto, existen evidencias de que estuvieron a la cabeza de dicha modernización. Las cartas del hacendado Joaquín García Icazbalceta a su hijo Luis fortalecen lo antes dicho.

La existencia misma de la formación de una compañía para la administración y manejo de las haciendas propiedad de la familia García Icazbalceta muestra la visión empresarial que tuvieron para no dividir sus propiedades, lo que hubiera significado fraccionar su capital y consecuentemente disminuir su potencialidad como negocio. Pero mantener la propiedad familiar unida implicó llevar a cabo el trabajo de coordinación y gestión necesario para que funcionara adecuadamente. Don Joaquín, primero, y su hijo Luis, más tarde, realizaban esta labor desde la ciudad de México y con sus visitas periódicas a las haciendas.

La coordinación y gestión de la compañía también significó la elaboración del reglamento con las funciones que tenían asignadas los propietarios, sus obligaciones y derechos correspondientes. Todo ello también 
nos habla de la modernidad administrativa de la empresa modelo de los García Icazbalceta, en la segunda mitad del siglo XIX.

Como puede apreciarse, la relevancia de estas misivas estriba en que documentan, entre otros muchos aspectos, las estrategias seguidas por la compañía García Icazbalceta Hermanos, para la adquisición o fabricación de maquinaria y contratación del personal para su instalación, decisiones que recayeron especialmente en don Joaquín, en quien sus hermanos depositaron su confianza, dejándole casi por completo la representación y administración de la empresa, en vista de sus dotes e inteligencia mostrada para los negocios desde muy joven pues, si bien es cierto que Joaquín García Icazbalceta se distinguió por su erudición y sabiduría con sus trabajos históricos y bibliográficos, también destacó en su actuación como hacendado.

De esta forma, se advierte que parte de sus estrategias consistieron, en primer lugar, en solicitar al extranjero catálogos, diseños y presupuestos de maquinaria a una o dos casas especializadas, para comprar o mandar construir a reconocidos distribuidores y fabricantes gran parte de la maquinaria de la mejor calidad, tales como calderas, básculas, arados, coas, entre otras herramientas; para ello aprovechó su red de corresponsales y comisionistas en Francia y en Estados Unidos que, además de conseguirle libros, le surtieron diversos artículos para sus negocios.

El segundo paso estratégico fue estudiar y comentar las adecuaciones de los aparatos con algún fabricante establecido en México. Posteriormente, contratar los servicios de un práctico o profesionista de la ciudad, preferiblemente de origen extranjero, pues esto era para don Joaquín sinónimo de una mejor preparación y conocimiento de adelantos tecnológicos; después acordar los honorarios, requerimientos, traslado y tiempo para realizar los trabajos en las fincas. De esta manera, se evitaba pagar los altos honorarios y viáticos del personal enviado por los fabricantes para instalar las máquinas. Finalmente, también prefirió contratar ayudantes en el lugar donde se realizarían los trabajos o, en todo caso, emplear a los mismos peones de las haciendas porque tendrían mayor aceptación entre los mismos residentes. Todo lo anterior, con la consulta y aceptación de su hermano Lorenzo y de su hijo Luis.

Esta práctica, en la cual el hacendado al final combinó lo nacional con lo extranjero, aseguraba por una parte la adquisición de maquinaria 
novedosa y de mejor calidad, ya fuera norteamericana o francesa, aunque no tuviera en esto ningún ahorro, pues por lo general su precio y envío era más alto. La reducción de costos la obtenía con la contratación de personal experimentado pero establecido en México, y aun economizaba más con la habilitación de los peones como ayudantes.

Existen diferencias en la contratación del personal en cuanto a tiempo y sueldo. En el caso del médico y del abogado se les empleaba por tiempo indefinido para atender todo tipo de eventos y se les pagaba una iguala mensual. Otros trabajos requerían los servicios temporales de algún práctico, como la instalación de una máquina. Una modalidad más fue solicitar la asesoría o supervisión de personal altamente calificado para el caso de obras de mayor envergadura, a quienes se les pagaban honorarios más altos a cambio de tener seguridad al realizar la obra con los empleados locales. Un ejemplo de esto fue la intervención de los arquitectos-ingenieros Hidalga García.

El conjunto de todos los elementos citados refleja los conocimientos, carácter y visión empresarial de Joaquín García Icazbalceta además de su acertada, como oportuna, toma de decisiones, todo lo cual coadyuvó a la temprana modernización de las haciendas de la compañía García Icazbalceta Hermanos, cuyo fin estaba encaminado a cumplir con sus metas de aumentar la producción, mejorar la calidad de sus productos y disminuir los costos.

Cabe señalar que, desde épocas anteriores, estas haciendas ocuparon un lugar importante y sobresalían, entre otras cosas, por ser de las pocas que estuvieron en manos de la misma rama Icazbalceta por espacio de 150 años. ${ }^{65}$ De su importancia a mediados del siglo XIX, nos habla el "Decreto de contribuciones de 1851", pagadas por las haciendas ubicadas en los partidos de Cuernavaca, Yautepec, Tetecala y Jonacatepec. En este último se localizaban las haciendas de los hermanos García Icazbalceta: la hacienda de Tenango estaba entre las únicas cuatro clasificadas de primera clase (San Carlos, Tenextepango, Cuahuixtla y Tenango) y pagaba una contribución de 208 pesos. La de Santa Clara estaba entre las siete consideradas de segunda clase con un pago de 183 pesos. Finalmente, la de San Ignacio se

65 Toussaint, “Ubicación y descripción arquitectónica de las haciendas...”, en Haciendas de Morelos, p. 353. 
le clasificó de quinta clase y pagaba 75 pesos. ${ }^{66}$ Una constante de los sucesivos propietarios fue mantenerse en los primeros lugares.

Si bien las estadísticas disponibles de la producción de azúcar en México abarcan especialmente a partir de la última década del siglo XIX, ${ }^{67}$ para los años referidos en este artículo -1877-1894- se tienen pocos datos de producción por cada una de las casi treinta haciendas del estado de Morelos, como también es escaso otro tipo de documentación. ${ }^{68}$ Esto dificulta determinar con exactitud la efectividad de las estrategias de la compañía García Icazbalceta Hermanos. No obstante, un indicador de los logros alcanzados son los aumentos anuales en la producción de panes de azúcar a que se hizo referencia en este artículo. Otros podrían ser los premios que obtuvieron en algunas exposiciones internacionales por la calidad del azúcar que en éstas se producía. Por ejemplo, en la de París, en 1889, la hacienda de Tenango obtuvo medalla de plata, lo mismo que la hacienda de Cuahuixtla y Atlacomulco; mientras que la de Santa Clara, medalla de bronce igual que la hacienda de Calderón. Una muestra más de sus buenos resultados es el primer lugar en producción de miel que obtuvieron Tenango y Santa Clara juntas, entre todas las haciendas morelenses, durante el bienio de 1898-1899, y en producción de azúcar estuvieron en el segundo lugar. Luis García Pimentel era el único propietario en ese entonces y supo capitalizar los conocimientos y las enseñanzas de su padre. ${ }^{69}$

En este artículo sólo hemos presentado algunos aspectos y vicisitudes del proceso modernizador de las haciendas de los García Icazbalceta a partir de la documentación generada por los mismos propietarios de la

66 Brígida von Metz et al., Haciendas de Morelos, p. 141-142. Cita el “Decreto de contribuciones, ordenadas según su tamaño, el monto de impuesto que pagaban y clase fiscal a la que pertenecían".

67 Horacio Crespo y Enrique Vega Villanueva, Estadísticas históricas del azúcar en México.

68 Véase la nota 23, p. 17.

69 En el bienio 1898-1899, cuatro años después de la muerte de Joaquín García Icazbalceta, la producción de miel de Tenango y Santa Clara juntas, fue de 2440510 toneladas, superando a las otras 29 haciendas morelenses registradas. En tanto que en producción de azúcar las haciendas de Luis García Pimentel registraron 1764762 toneladas, superadas solamente por la hacienda de Cuahuixtla con una producción de 2006295 toneladas. Crespo y Vega Villanueva, Estadísticas históricas del azúcar en México, p. 78. 
compañía, punto de vista del que se tienen pocos testimonios y que, con todas sus limitaciones y sesgos, nos aportan otros datos de lo que significó esa “modernización” en cuanto tiempos, trabajo y contratiempos propios de la situación económica y política por la que atravesaba el país en la segunda mitad del siglo XIX y en los años previos al movimiento revolucionario. 
